\title{
An innovative In-situ DRAINage system for advanced groundwater reactive TREATment (In-DRAIN-TREAT)
}

\author{
Bortone I. ${ }^{*}$, Santonastaso G. ${ }^{2}$, Erto A. ${ }^{3}$, Chianese S. ${ }^{2}$, Di Nardo A. ${ }^{2}$, Musmarra D. ${ }^{2}$ \\ ${ }^{1}$ School of Water, Energy and Environment, Cranfield University, College Road, Cranfield, MK43 OAL,UK \\ ${ }^{2}$ Dipartimento di Ingegneria, Università della Campania L. Vanvitelli, 81031 Aversa, Italy \\ ${ }^{3}$ Dipartimento di Ingegneria Chimica, dei Materiali e della Produzione Industriale, Università di Napoli Federico II, 80125, \\ Napoli, Italy *Corresponding author: E-mail: imma.bortone@cranfield.ac.uk
}

\begin{abstract}
The removal of groundwater contamination is a complex process due to the hydro-geochemical characteristics of the specific site, related maintenance and the possible presence of several types of pollutants, both organic and inorganic. In recent decades, there has been an increasing drive towards more sustainable treatment for contaminated groundwater as opposed to "intensive" treatments, i.e. with high requirements for onsite infrastructure, energy and resource use. In this study, a new remediation technology is proposed, combining the use of advanced drainage systems with adsorption processes, termed "In-situ reactive DRAINage system for groundwater TREATment" (In-DRAIN-TREAT). By taking advantage of the groundwater natural gradient, In-DRAIN-TREAT collects the contaminated groundwater via a drainage system and treats the polluted water directly into an active cell located downstream, avoiding external energy inputs. Preliminary results indicate the applicability and high efficiency of In-DRAIN-TREAT when compared with a permeable reactive barrier (PRB). In-DRAINTREAT is applied to remediate a theoretical aquifer with low permeability, contaminated by a $13 \mathrm{~m}$ wide hexavalent chromium $\left(\mathrm{Cr}^{\mathrm{VI}}\right)$ plume. This is achieved in less than a year, via a drain DN500, $32 \mathrm{~m}$ long, a $30 \mathrm{~m}^{3}$ treatment cell filled with activated carbon and no energy consumption. A comparison with permeable barriers also shows a preliminary $63 \%$ volume reduction, with a related $10 \%$ decrease of remediation costs. Keywords: in-situ remediation, passive groundwater treatment, adsorption processes, green remediation, hexavalent chromium $\left(\mathrm{Cr}^{\mathrm{VI}}\right)$
\end{abstract}




\section{Introduction}

Large-scale groundwater contamination, due to accidental or intentional releases of man-made chemical substances, is a worldwide environmental emergency. Vast numbers of polluted sites that contain unacceptable levels of toxic and persistent contaminants, such as heavy metals, PAHs and PCBs, require cleaning actions. The goal of groundwater remediation is to reduce the risk posed to human and environmental receptors by contaminants. However, this often requires expensive and large volume interventions, which are not always effective and can result in atmospheric emissions, which are harmful to the environment (EPA, 2004).

Several ex-situ and in-situ remediation technologies have been proposed over the years, most of which have a high maintenance combined with a long-term invasive treatment (Khalid et al., 2016; NRC, 1997). Many studies have confirmed that Pump \& Treat (P\&T) remains the most common approach in the remediation of groundwater contamination, used to remove a variety of dissolved materials, including VOCs, SVOCs, fuels, and explosive compounds (EPA, 2005; 1999). P\&T is an ex-situ technology where contaminated groundwater is extracted from the ground, treated overground and finally discharged or re-injected in the aquifer. Due to the aquifer's slow conductivity, contaminant dissolution and/or migration, P\&T often requires extended treatment periods (e.g. 10s to 100s of years) to reduce the contaminant levels to regulatory standards. These long periods of operation involve significant energy and associated operating and maintenance costs (Bortone et al., 2013a; EPA, 1999).

Designing and optimising an effective groundwater remediation technology are a complex process where both technical aspects (i.e. hydrological and geotechnical properties of the entire polluted aquifer, extent of the contaminated area, etc.), technology performance and costs must be considered for their high interdependence (NRC, 1997). Cost-efficient and ecological cleaning technologies could make a significant difference on a global scale (Divine et al., 2018; EPA, 2004). This has led to research on more sustainable treatment and solutions opposed to 
removal or containment actions, or "intensive" treatments with high requirements for on-site infrastructure, energy and resource use. Over recent decades, significant emphasis has been placed on the development of new in-situ contaminated land treatment methods in order to circumvent the inherent environmental destruction caused by traditional "invasive" ex-situ treatments (EPA, 2008; Carey et al., 2000).

More recently, remediation treatments such as in-situ bioremediation (ISBR) and in-situ chemical oxidation/reduction (ISCO/R) have been very successful in treating both groundwater and aquifer matrix in the saturated zone (Ceulemans and Labeeuw, 2013; Key et al., 2013). However, both the complexities of soils, hydro-geochemistry and chemical hazardous mixtures encountered tend to affect the application spectrum and efficiency of both ISBR and ISCO. This dictates an immediate and significant demand for more modular techniques to allow broadening the spectrum of scenarios where in-situ methods can be applied (EPA, 2004).

To overcome the high operating costs of P\&T systems, passive treatments, such as permeable reactive barriers (PRBs), have been proposed and implemented (Bortone et al., 2019; Gavaskar et al., 2000). Other alternatives include trench and gate system designs that rely on high permeability to capture groundwater and direct it through emplaced treatment media (Swartjes, 2011). A substitute concept using arrays of non-pumping vertically oriented wells filled with treatment media has been evaluated in several studies (Hudak, 2017; Bortone et al., 2019). Siphoned vertical wells and long horizontal reactive wells known as GeoSiphon/GeoFlow treatment systems (Phifer et al., 1999) and HRX Well (Divine et al., 2018) respectively, have also been investigated. The Geosiphon system consists of an upgradient, vertical in-situ treatment well ( $2 \mathrm{~m}$ diameter), containing a permanent permeable treatment media, where a water flow is passively produced via a siphon from the well to a surface stream (or ground surface). Siphon flow is induced by the natural hydraulic head difference between the well and a surface stream located at a specific distance. The main drawback is that the Geosiphon system 
can only be applied to shallow aquifers. The HRX Well system also uses large and very long horizontal wells, which are set up in parallel to the groundwater flow direction. The higher conductivity of the wells, filled with granular reactive media, allows for the capture of the contaminated water, which is treated simultaneously. The main HRX Well system drawback is the use of a single type of material per well, (e.g. zero valent iron) which can only act on specific pollutants. Further to this, as the wells are installed underground, they are not easily accessible, and the replacement of the filled materials requires costly engineering processes.

Given that operating costs remain a significant market barrier for the deployment of remediation technologies, this study introduces a new integrated treatment concept for groundwater plume remediation, termed In-DRAIN-TREAT, an "In-situ reactive horizontal advanced DRAINage system for groundwater TREATment". In-DRAIN-TREAT is based on the concept to "trap and treat" the contaminated groundwater, which is achieved by enhancing the hydrological convey of pollutants stream and locating the treatment into an in-situ "controlled conditions cell" with a substantial volume and cost reduction.

In-DRAIN-TREAT is an innovative approach, alternative to PRB and P\&T application, as it leverages an engineered permeability as opposed to a passively focused ground-water flow. However, it is unique in relying on small-diameter horizontal drains to do so, and the possibility to treat the collected contaminated water in small/optimal volume treatment cells, where an easily monitored multi-reactive system can be adopted.

The cell of In-DRAIN-TREAT, being separated from the water collection, can be filled with a variety of reactive materials and/or sorbents at controlled conditions. Many different types of treatment media are available, including activated carbon, zero valent iron, biodegradable particulate organic matter (Erto et al., 2015; Chen et al., 2011). Therefore, this new concept could be used to address a wide range of contaminants (such as heavy metals, organic compounds, PCBs etc.) and multiple contaminations, simultaneously. In addition, by using thin 
horizontal drains, In-DRAIN-TREAT can be applied to deep aquifers and be less invasive than current technologies. The horizontal technology is also able to reach sensitive/difficult aquifers, by facilitating the contact beneath infrastructures (roads, building, etc.) and can deviate the polluted water where it is possible to install the treatment cell. Furthermore, horizontal environmental wells offer some practical advantages over the use of the vertical wells in many applications, especially in low permeability sites (EPA, 2005).

The technology of horizontal drains is widely known in helping to lower the water table in a slope and a common solution for stabilising hillsides (Kompani-Zare and Zhan, 2006). These systems are installed by drilling horizontally and installing perforated or slotted pipes into the slope to collect water and convey it to a suitable discharge point (Rahardjo et al., 2003). This is the concept on which In-DRAIN-TREAT is based, allowing for easier construction, implementation, operation and access to the adsorbing/reactive material for contaminant removal.

This paper presents a conceptual and numerical evaluation of In-DRAIN-TREAT, with the objective to demonstrate its cost-effectiveness, allowing an efficient removal of dissolved and persistent contaminants from aquifers, such as hexavalent chromium $\left(\mathrm{Cr}^{\mathrm{VI}}\right)$, and requiring minimal infrastructure. A model for predicting the efficiency of In-DRAIN-TREAT technology for remediating contaminated, low-permeability soils was developed and a preliminary optimisation was carried out. Finally, a preliminary cost analysis was performed, also including a comparison with alternative groundwater remediation technologies (i.e. PRB).

\section{Material and methods}

\subsection{Technology description}

For the capture of the contaminated water, In-DRAIN-TREAT utilises an inlet submerged horizontal perforated drain oriented parallel to the groundwater flow, directly connected with 
a reactive cell, which is located at the other end of the drain, as represented in Figure 1. The treatment adopted within the reactive cell is dependent of the type of contamination.

The design of In-DRAIN-TREAT consists mainly of: i) the definition of the drain-cell combo characteristics (i.e. number of drains and cells); ii) optimisation of In-DRAIN-TREAT geometrical parameters such as the drain diameter $(D)$, the number, drain length $\left(L_{\text {in }}\right.$ and $\left.L_{o u t}\right)$, screen length of inlet and outlet drains, $\left(L_{p-\text {-in }}\right.$ and $\left.L_{p-o u t}\right)$, the plume-to-drain distance $(E)$, and the treatment cell dimensions, $\left(W_{\text {cell }}\right.$ and $\left.L_{\text {cell }}\right)$, as schematised in Figure 1.

In-DRAIN-TREAT design enhances natural "flow-focusing" behaviour induced by the engineered hydraulic conductivity drain-aquifer contrast, to passively capture and treat proportionally large volumes of groundwater within the "in-situ treatment cell" (Figure 1). The higher permeability of the drain, in fact, creates a "cone of depression or influence" diverting the water, at an accelerated rate, directly to the reactive area, as shown in Figure 1. The drains can be horizontal or slanted drains, with different screened sections, parallel and perpendicular to groundwater flow direction, depending on the case study characteristics. The shape, rate, expansion $\left(E_{\text {inf }}\right)$ and depth $\left(H_{\text {inf }}\right)$ of this drawdown cone (Figure 1c) depend on a combination of the drain diameter and length and the aquifer hydraulic properties (Kompani-Zare and Zhan, 2006).

The treatment cell is a waterproof area filled with reactive material, vertically developed and accessible from the soil surface. This allows more flexibility on the type of treatment to use, whose dimensions can be optimised and easily monitored. Moreover, it allows to directly intervene in case of release of toxic by-products, when reactive media interact with the contaminants, or when clogging phenomena occur. A multi-reactive treatment can be adopted, by also having a chance to use combined treatment technologies. In addition, a vertical baffle, of designed height $\left(H_{b}\right)$ located in the middle of the cell (Figure 1b), allows a disruption of the flow pattern and provides bottom to top and top to bottom flow in the cell. In this way, the 
contact length of the contaminant with the reactive material and, simultaneously, the residence time in the cell are easily increased, without further excavation. In addition, to maintain the natural hydraulic gradient in the treatment cell, part of the inlet and outlet drain is impermeable, as schematised in Figure 1a, where the permeable part is represented by a dotted line.

Based on this principle, In-DRAIN-TREAT utilises natural hydraulic driving forces to induce accelerated flow rates (greater than natural) for remediation, similar to conventional P\&T systems, but improved upon them through passive operation (with no external power requirements), thereby significantly lowering operating and maintenance costs.

The treatment technique adopted in the In-DRAIN-TREAT cell is a classical adsorption process (Erto et al., 2011; Bortone et al., 2013b). 

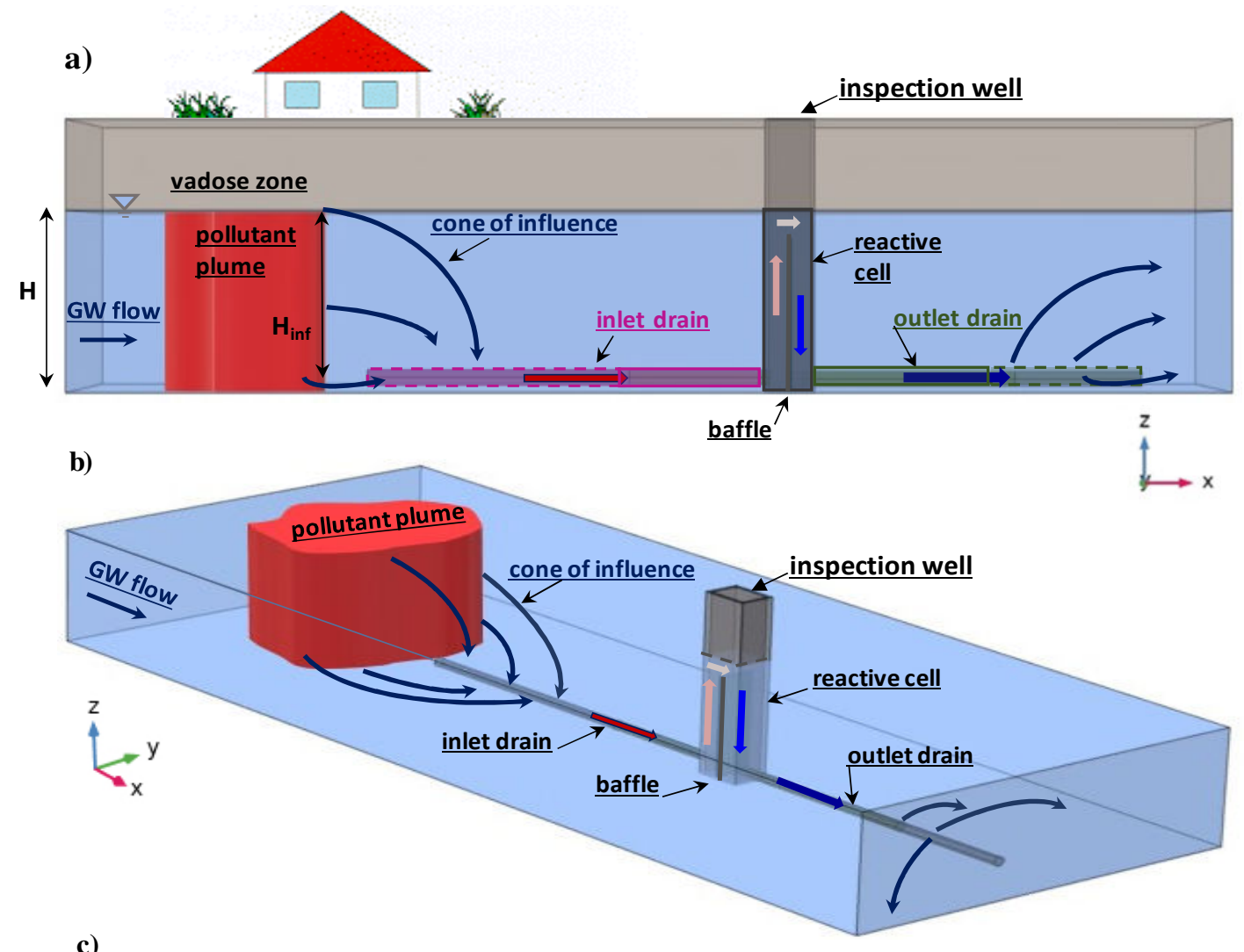

c)

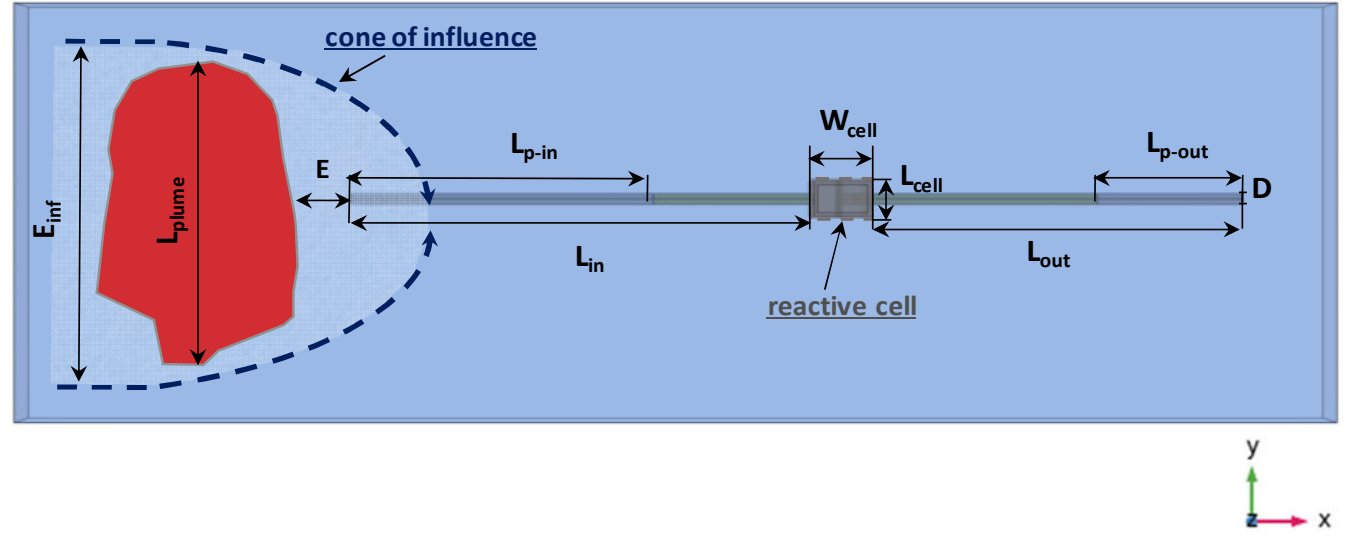

Figure 1. In-DRAIN-TREAT schematisation respectively in a) 2D domain, b) 3D domain c) main design parameters.

\subsection{Numerical model}

The governing equation describing the $3 \mathrm{D}$ transport of contaminant with concentration, $C$, over time, $t$, through an aquifer is described as follows (Fetter, 1993; Gelhar et al., 1992): 
$\theta \frac{\partial C}{\partial t}=\theta \nabla \cdot\left(D_{h} \nabla C\right)-\theta \bar{u} \nabla C$

Which combines the effect of advection and dispersion mechanisms in soil with porosity $\theta$, respectively described via the velocity vector, denoted with $\bar{u}$, and the hydrodynamic dispersion coefficient, denoted with $D_{h}$. In Eq. (1), it is assumed that no natural attenuation takes place; hence, there is no adsorption term in the aquifer. Differently, adsorption occurs in the treatment cell, for which Eq. (1) modifies as:

$\theta_{c} \frac{\partial C}{\partial t}=\theta_{c} \nabla \cdot\left(D_{h} \nabla C\right)-\theta_{c} \bar{u} \nabla C-\rho_{c} \frac{\partial \omega}{\partial t}$

In Eq. (2) the parameters of the cell have been indicated with the subscript " $c$ ". The last term on the right-hand side of Eq. (2) describes the capture of the pollutant dissolved in water by the adsorbing media, i.e. the variation of the adsorption capacity, $\omega$, over time, $t$, corresponding to

$\rho_{c} \frac{\partial \omega}{\partial t}=k_{t} a\left[C-C^{*}(\omega)\right]$

where $\rho_{c}$ is the bulk density of the media, $k_{t}$ is the mass transfer coefficient for adsorption reaction, $a$ is the external specific surface area of adsorbent particles and $C^{*}(\omega)$ is the term deriving from the adsorption isotherm of the contaminant on the adsorbent material (i.e. the equilibrium concentration between pollutant concentration in the liquid phase and the amount adsorbed over the solid surface).

More details on the equation system adopted for numerical simulations are reported in the Supplementary Material (SM). 
The equation system (1) - (3), with the related initial and boundary conditions (reported in Supplementary Material SM), were solved numerically via the finite element method implemented in COMSOL Multi-physics® software (Bortone et al., 2019), which allowed to predict the contaminant transport in the aquifer, its capture in the treatment cell and the groundwater flux over time (Tabatabaian, 2014). Specifically, COMSOL pre-defined modules "Darcy's Law" and "Solute Transport" were used to describe the subsurface flow and solute transport and to solve Eqs. SM(1) - SM(4), whilst the adsorption and desorption phenomena both in the reactive cell and barrier (Eqs. $\mathrm{SM}(5)$ and $\mathrm{SM}(6))$ were implemented via an ad-hoc "user-defined physic".

\subsection{Case Study}

For the numerical proof of concept of the In-DRAIN-TREAT technology, a theoretical, unconfined aquifer polluted by hexavalent chromium $\left(\mathrm{Cr}^{\mathrm{VI}}\right)$ was examined. The computational domain was set up according to the dimensions indicated in Figure 2. As described in section 2.2., the fate and transport of $\mathrm{Cr}^{\mathrm{VI}}$ was simulated by incorporating the mechanisms of advection, diffusion and dispersion in the aquifer, whose parameters are listed in Table 1. The domain is considered as a homogeneous, porous medium along its entire depth, with hydraulic conductivity of $8 * 10^{-5} \mathrm{~m} / \mathrm{s}$ and groundwater flow west-east oriented. Similar soil characteristics were adopted by the authors in previous case studies (Santonastaso et al., 2018; Musmarra et al., 2015; Erto et al., 2014). Constant head boundaries were used to upgradient and downgradient model boundaries to maintain an average hydraulic gradient of $0.2 \%$ (Eq. $\mathrm{SM}(7))$. Simulated hydraulic conductivity in the treatment cell was $10^{-2} \mathrm{~m} / \mathrm{s}$. Effective porosity was $30 \%$ in the aquifer and $40 \%$ in the cell. The $\mathrm{Cr}^{\mathrm{VI}}$ plume was assumed with a constant concentration equal to $100 \mu \mathrm{g} / \mathrm{L}$ along the whole aquifer depth, with a cylindrical shape area of over $220 \mathrm{~m}^{2}$, as shown in Figure 2a, and there is no ongoing contaminant source (Eq. SM(8)). 
The In-DRAIN-TREAT cell was filled with activated carbon, Aquacarb $207^{\mathrm{EA}}$. The characteristics of the area analysed with key site parameters, and the main properties of the adsorbing material are listed in Table 1.

Table 1. Hydraulic and geological parameters of the study area.

\begin{tabular}{lc}
\hline \multicolumn{1}{c}{ Aquifer characteristic } \\
\hline Computational area, $A$ & $0.01 \mathrm{~km}^{2}$ \\
Polluted area total extent, $A_{p}$ & $224 \mathrm{~m}^{2}$ \\
Aquifer average piezometric level, $h_{w}$ & $5.4 \mathrm{~m}$ \\
Piezometric gradient, $J$ & $0.002 \mathrm{~m} / \mathrm{m}$ \\
Soil porosity, $\theta$ & 0.3 \\
Dry soil bulk density, $\rho_{s}$ & $1,400 \mathrm{~kg} / \mathrm{m}^{3}$ \\
Hydraulic conductivity, $K_{s}$ & $8 * 10^{-5} \mathrm{~m} / \mathrm{s}$ \\
Longitudinal dispersivity, $\alpha_{x}$ & $1 \mathrm{~m}$ \\
Transverse dispersivity, $\alpha_{y}$ & $0.1 \mathrm{~m}$ \\
Initial concentration of plume, $C^{C r_{v}}$ & $100 \mu \mathrm{g} / \mathrm{L}$ \\
\hline \multicolumn{1}{c}{ In-DRAIN-TREAT characteristics } & \\
\hline Reactive media in treatment cell & Activated carbon \\
Cell dry bulk density, $\rho_{c}$ & $520 \mathrm{~kg} / \mathrm{m}^{3}$ \\
Cell porosity, $\theta_{c}$ & 0.4 \\
Cell hydraulic conductivity, $K_{c}$ & $0.01 \mathrm{~m} / \mathrm{s}$ \\
Mass transfer coefficient, $k_{t} a$ & $0.010211 / \mathrm{s}$ \\
Inlet drain length, $L_{i n}$ & $30-35 \mathrm{~m}$ \\
Outlet drain length, $L_{\text {out }}$ & $30-35 \mathrm{~m}$ \\
Drain diameter, $D$ & $0.5-0.7 \mathrm{~m}$ \\
Cell width, $W_{\text {cell }}$ & $2-3 \mathrm{~m}$ \\
Cell Length, $L_{\text {cell }}$ & $2-3 \mathrm{~m}$ \\
Cell Depth, $H_{\text {cell }}$ & $5.5 \mathrm{~m}$ \\
Baffle height, $H_{b}$ & $4.5 \mathrm{~m}$ \\
Drain distance from the plum, $E$ & $0-5 \mathrm{~m}$ \\
\hline
\end{tabular}

Figures $2 \mathrm{a}$ and $2 \mathrm{~b}$ represent the geometry of the pollutant tested and the computational mesh used for the simulations, respectively. The considered mesh was a physics-controlled mesh of 2,239,455 domain elements, 140,623 boundary elements, and 7,746 edge elements, with a maximum element size of $0.16 \mathrm{~m}$ and a minimum of $0.0025 \mathrm{~m}$. Verification of numerical accuracy of the model was achieved through the estimation of numerical errors during the simulations. The finite element discretization was solved via considering two adaptive accuracy requirements, subject to relative and absolute tolerances: one for the time-stepping (solver) error and one for the algebraic equation (solver) error (Söderlind and Wang, 2006). 
The relative residual and the algebraic error estimates were verified to maintain below the order of magnitude of $10^{-12}$, with no recorded failures of the adaptive step-size and of the algebraic nonlinear solver.

A range of dimensions for In-DRAIN-TREAT parameters were analysed to determine the best performing configuration, as shown in Table 1. In all the configurations, both inlet and outlet drains were oriented parallel to the aquifer floor direction and assumed to have horizontal screens not completely permeable, to maintain a hydraulic gradient in the treatment cell (Figure 2a).
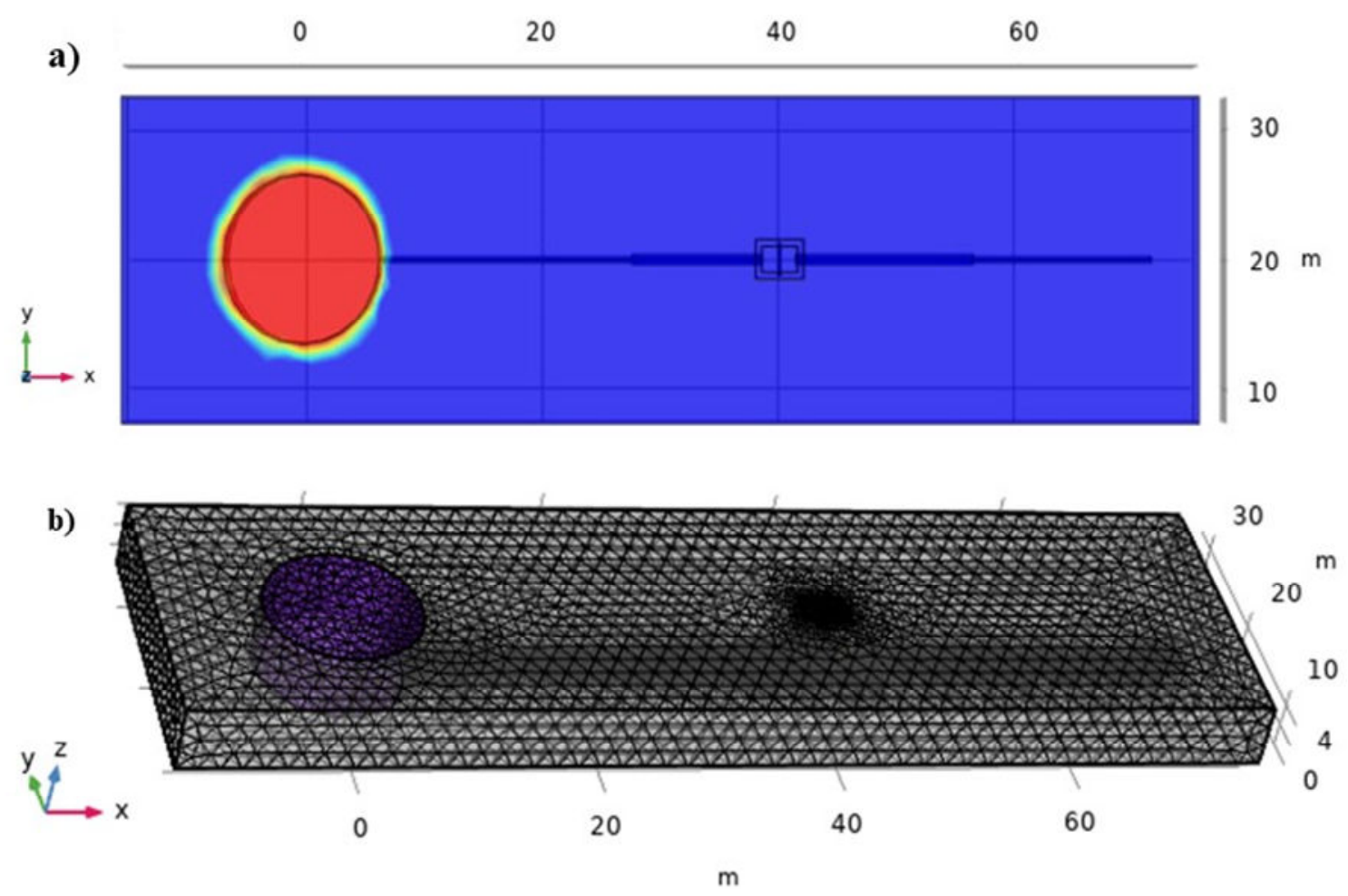

Figure 2. Case study a) geometry of the domain and b) mesh adopted for 3D numerical simulations.

In the present study, the adsorption isotherm considered for Eq. (3) is the Langmuir model expressed by the following equation: 
$\omega=\frac{\omega_{\max } K_{L} C}{1+K_{L} C}$

Adsorption properties of the investigated system were retrieved from previous experimental studies of our research group (Di Natale et al., 2015). Langmuir parameters $\omega_{\max }$ and $K_{L}$, used in Eq.(4), are further described in Di Natale et al. (2015) ,at a temperature of $10^{\circ} \mathrm{C}$ and they are equal to $14.4 \mathrm{mg} / \mathrm{g}$ and $5.83 * 10^{-2} \mathrm{~L} / \mathrm{mg}$, respectively. The mass transfer coefficient was calculated by means of the typical dimensionless equations as reported in Perry and Green (2007), in line with those reported in Di Natale et al. (2015).

\section{Results}

To obtain the best configuration for the case study examined, a sensitivity analysis was carried out by varying the most crucial In-DRAIN-TREAT parameters, i.e. the drain length $\left(L_{i n}\right.$ and $\left.L_{\text {out }}\right)$, diameter $(D)$, and distance from the plume $(E)$, for which the range of considered values are listed in Table 1. The target concentration was the Italian threshold limit $\left(C_{\text {lim }}\right)$ of $5 \mu \mathrm{g} / \mathrm{L}$ for $\mathrm{Cr}^{\mathrm{VI}}(\mathrm{LD}, 2006)$ in the whole aquifer. The best performing scenario was achieved with InDRAIN-TREAT parameters as those listed in Table 2 and shown in Figure 3.

The sensitivity analysis showed that by varying the diameter and the permeable screen length of the inlet drain, the cone of influence increased but this also resulted in an increase in the hydraulic height in the treatment cell, thus deviating the water flow direction. Consequently, balancing all with the outlet drain characteristics proved to be a crucial aspect of design and technology effectiveness. In addition, the closer the inlet drain was to the contaminant plume the faster the contamination plume was collected. In this way, dilution phenomena were less 
enhanced and mainly the contaminated water was directed to the cell.

Table 2. In-DRAIN-TREAT optimal configuration parameters.

\begin{tabular}{lc}
\hline \multicolumn{2}{c}{ In-DRAIN-TREAT parameters } \\
\hline Inlet drain length, $L_{\text {in }}$ & $32 \mathrm{~m}$ \\
Inlet drain permeable screen, $L_{p \text {-in }}$ & $21 \mathrm{~m}$ \\
Outlet drain length, $L_{\text {out }}$ & $30 \mathrm{~m}$ \\
Outlet drain permeable screen, $L_{p-\text { out }}$ & $15 \mathrm{~m}$ \\
Drain diameter, $D$ & $0.5 \mathrm{~m}$ \\
Cell width, $W_{\text {cell }}$ & $3 \mathrm{~m}$ \\
Cell Length, $L_{\text {cell }}$ & $2 \mathrm{~m}$ \\
Cell Depth, $H_{\text {cell }}$ & $5.5 \mathrm{~m}$ \\
Baffle height, $H_{\text {baffle }}$ & $4.5 \mathrm{~m}$ \\
Drain distance from the plume, $E$ & $0 \mathrm{~m}$ \\
\hline
\end{tabular}

A representation of the hydrodynamics of the aquifer under the optimal In-DRAIN-TREAT configuration is shown in Figures 3 and 4, with reference to specific sections: A-A'(Figure 4a), B-B' (Figure 4b), C-C' (Figure 4c). Specifically, section A-A' plot shows the hydraulic head variation longitudinally to the whole configuration, while sections B-B' and C-C' plots, perpendicularly to the groundwater flow direction, respectively at the In-DRAIN-TREAT inlet (B-B') and outlet (C-C') impermeable part. The initial cylindrical shape area of the polluted plume is also shown, with localisation of the reactive cell in the domain. As highlighted in light blue in Figure 3 and in the cross sections sketched in Figure 4, the inlet drain of $0.5 \mathrm{~m}$ diameter with a permeable screen $\left(L_{p-i n}\right)$ long $21 \mathrm{~m}$ creates a cone of depression extended for approximately $20 \mathrm{~m}$ width $\left(E_{i n f}\right)$ and $0.12 \mathrm{~m}$ depth $\left(H_{i n f}\right)$ from the top of the aquifer corresponding to $5.5 \mathrm{~m}$ (Section A-A'). 


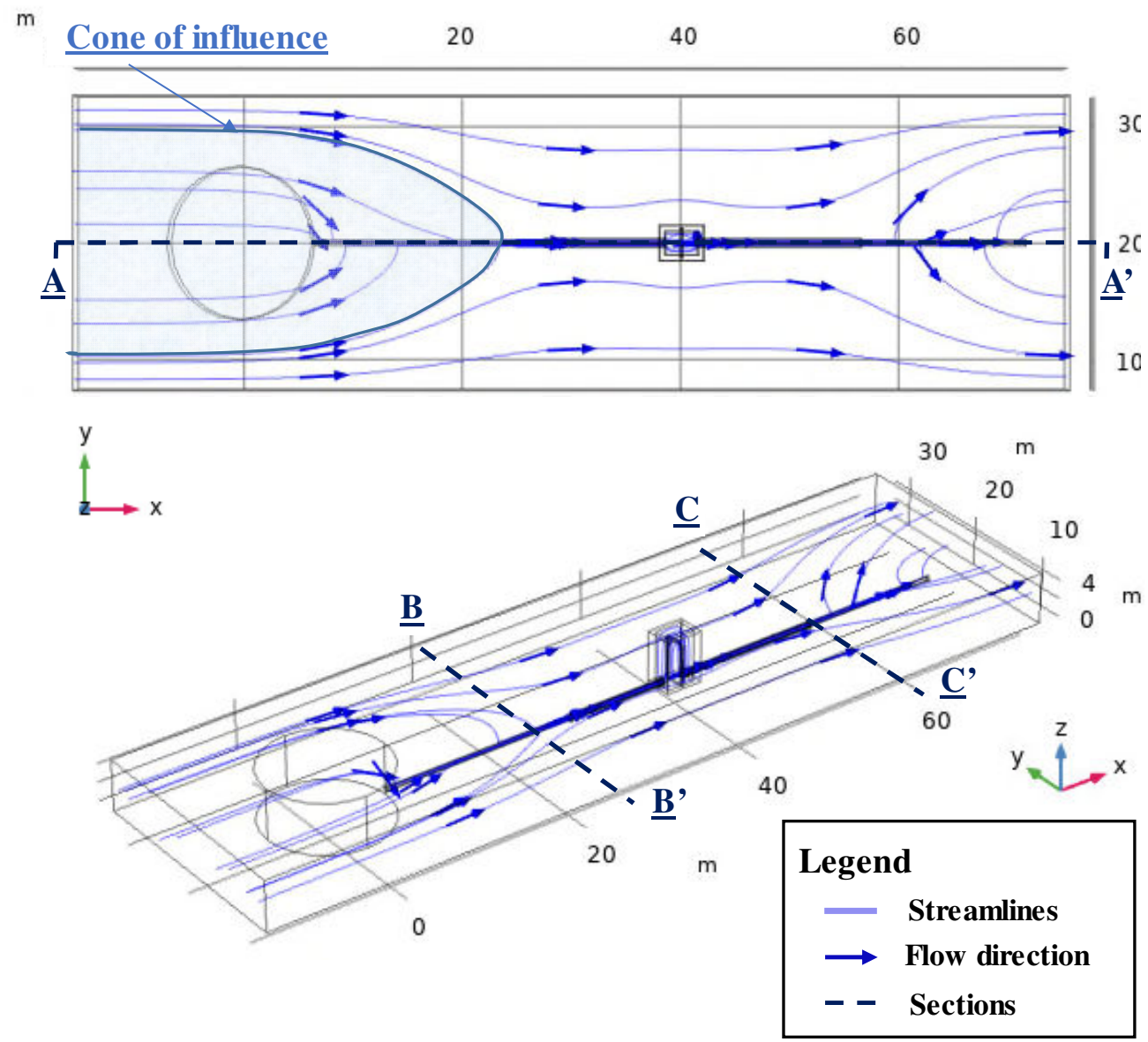

Figure 3. Aquifer hydrodynamics with In-DRAIN-TREAT, with localization of sections $\underline{\mathrm{A}-\mathrm{A}^{\prime}}, \underline{\mathrm{B}-\mathrm{B}^{\prime}}$ and $\underline{\mathrm{C}-\mathrm{C}^{\prime}}$. 
a)
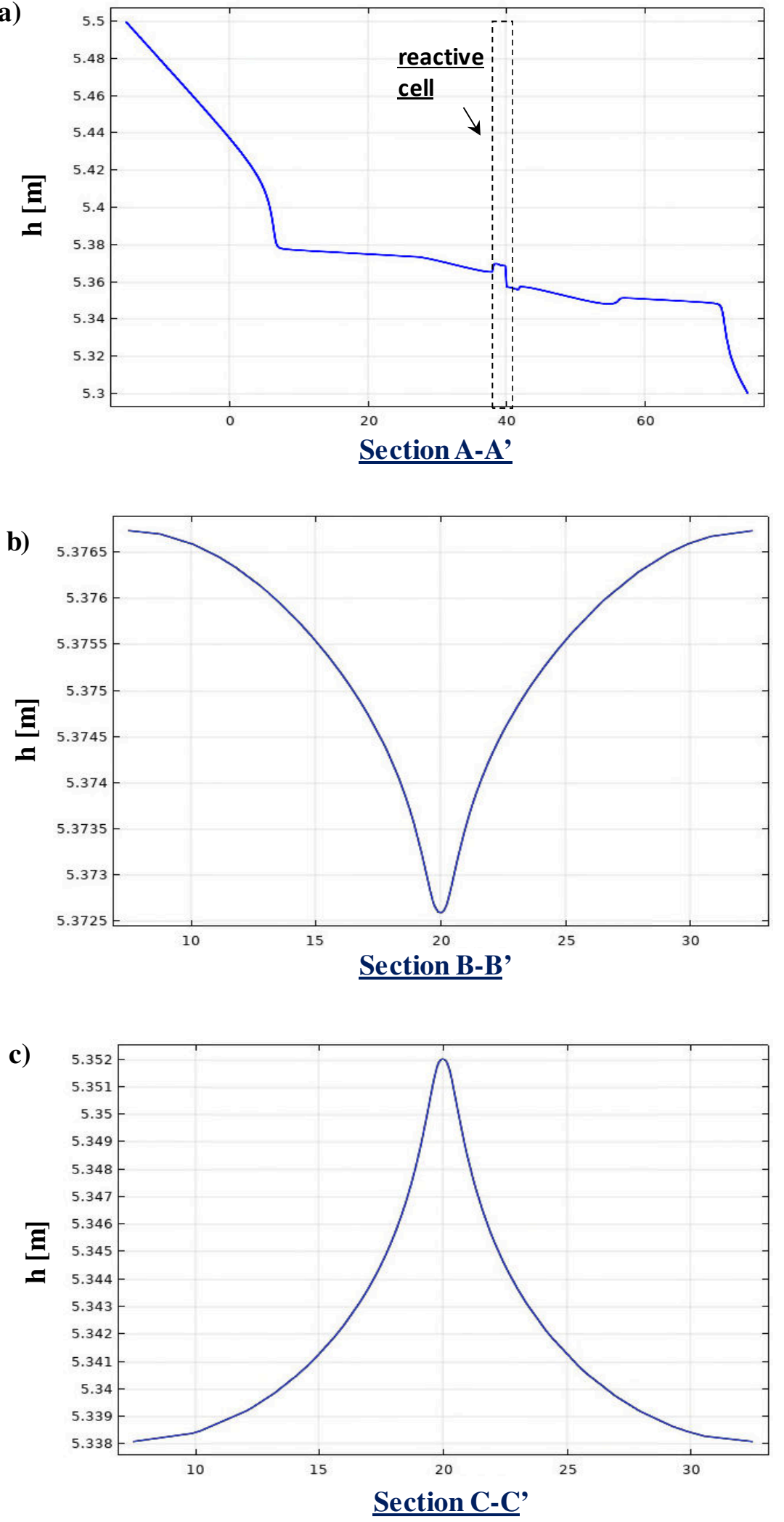

Figure 4. Hydraulic head variation at sections a) $\underline{A-A^{\prime}}$, b) $\underline{B-B}$ ' and c) $\underline{C-C}$. 
Figure 5 shows the effectiveness of the designed technology, by representing the 3D isoconcentrations of $\mathrm{Cr}^{\mathrm{VI}}$ over time, including the position of In-DRAIN-TREAT. Specifically, to provide clearer and more readable results, all $\mathrm{Cr}^{\mathrm{VI}}$ concentration values above $50 \mu \mathrm{g} / \mathrm{L}$ are represented in red, whilst graduations of light blue, green and orange highlight concentrations above the regulatory limit, $C_{l i m}$, equal to $5 \mu \mathrm{g} / \mathrm{L}$.

As shown, the pollutant is almost completely captured after 1 year of simulation and $\mathrm{Cr}^{\mathrm{VI}}$ concentration values are lower than $C_{l i m}$, both in the In-DRAIN-TREAT cell and most of the domain. This result is further highlighted in the breakthrough curves reported in Figure 8.

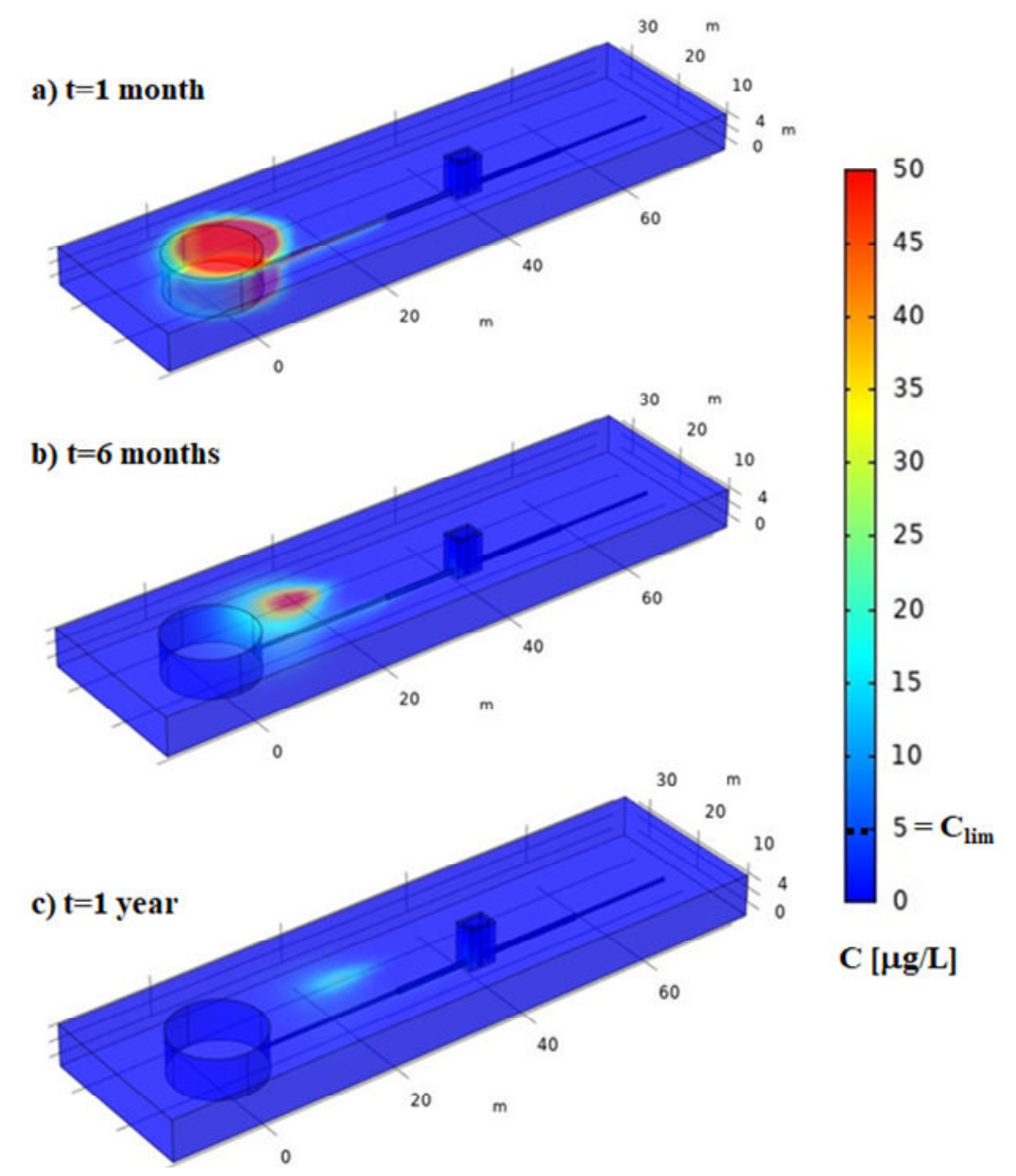

Figure 5. Chromium concentration plume after (a) 1 month, (b) 6 months and (c) 1 year of InDRAIN-TREAT application. 
Together with the contaminant capture, adsorption and desorption phenomena inside the treatment cell were also investigated by considering the $\mathrm{Cr}^{\mathrm{VI}}$ mass adsorbed per gram of adsorbent $(\omega)$ over the simulation time, as shown in Figure 6. The values of $\omega$ were obtained from Eqs. SM(5)-SM(6) and SM(4) (see Supplementary Material SM). The adsorbing material was depicted with a light grey colour, which becomes darker by increasing the amount of adsorbed chromium, $\omega$. As shown, by the flowing of the polluted water in the treatment cell, $\omega$ increases over time until the cell appears fully saturated (5 years). After 5 years, desorption phenomena start cleaning out the entire cell, and at 30 years, the adsorbing material appears clean again, i.e. with $\omega$ equal to $0 \mathrm{mg} / \mathrm{g}$. Figure 6 highlights the retardation of adsorption treatment over time and when the cell is fully saturated. Such retardation phenomena will allow for the removal of the reactive material once it is fully saturated (i.e. after 5 years), enhancing the groundwater protection potential of the technology.

In addition, for the same case study, a Permeable Adsorptive Barrier (PAB), i.e. a particular type of PBR but filled with adsorbing material (the same as the one adopted for In-DRAINTREAT), was dimensioned. The two technologies were compared in terms of the volume of adsorbing material $\left(V_{a d}\right)$ and remediation cost $\left(C_{R}\right)$, whose corresponding results are listed in Tables 3 and 4.

The PAB design required a smaller computational domain, but the hydraulic gradient of $0.2 \%$ and the same parameters listed in Table 1 were considered. In line with the practical design standards (Gavaskar et al., 2000) the barrier was placed in a trench perpendicular to the groundwater flow direction and design by following the procedure as described in Erto et al. (2011). Furthermore, it was located at the same distance of the treatment cell (i.e. distance equal to $L_{i n}=32 \mathrm{~m}$ ), as shown in Figure 7, to allow for a thorough comparison of the two technologies. As a result, the PAB necessary to intercept and treat the entire contaminant plume over time was $0.8 \mathrm{~m}$ wide $(W)$, and $19 \mathrm{~m}$ long $(L)$. 

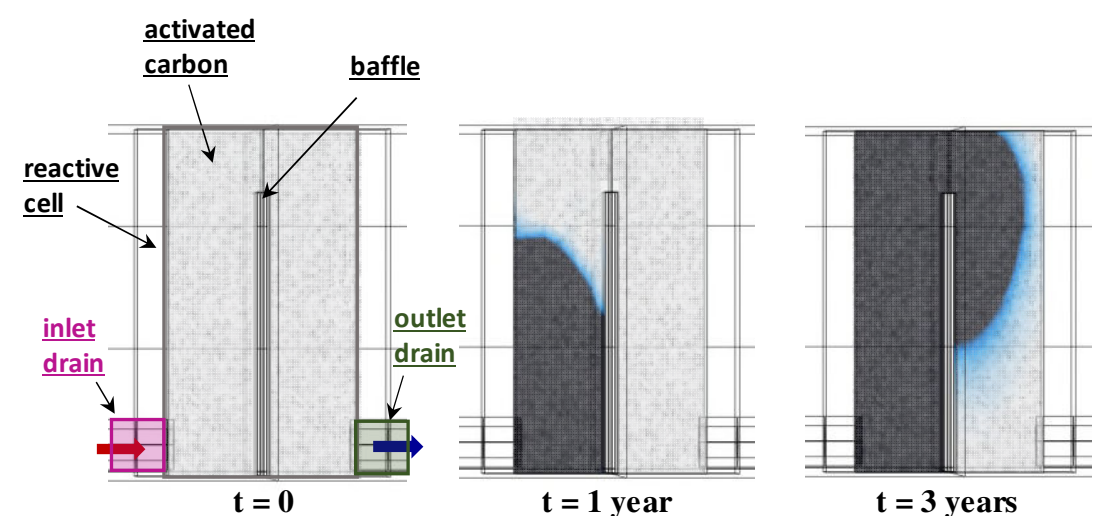

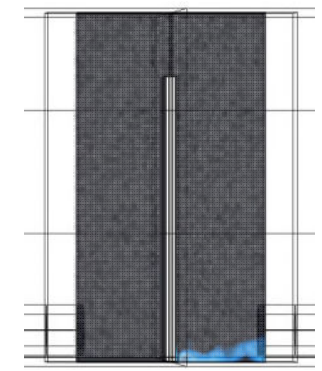

$\mathbf{t}=\mathbf{5}$ years

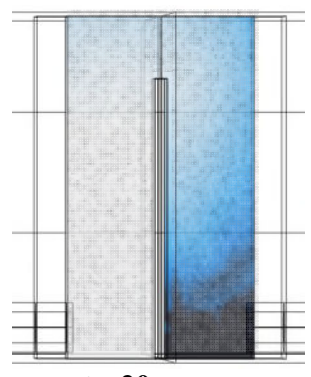

$\mathbf{t}=20$ years

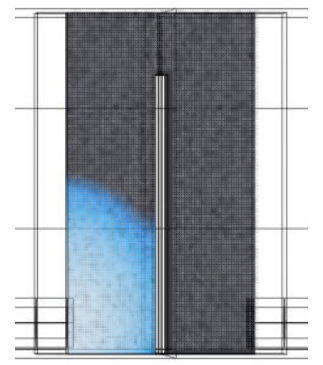

$\mathbf{t}=10$ years

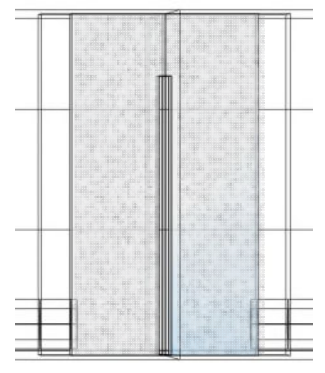

$\mathbf{t}=25$ years $\mathbf{t}=\mathbf{3}$ years

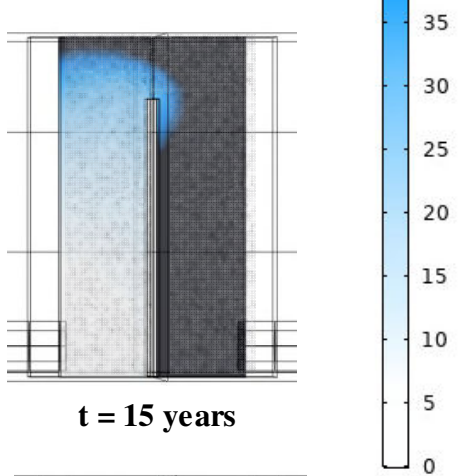

$\omega[\mathrm{mg} / \mathrm{g}]$

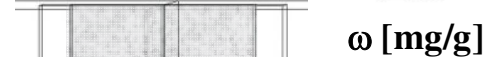

$\mathbf{t}=30$ years
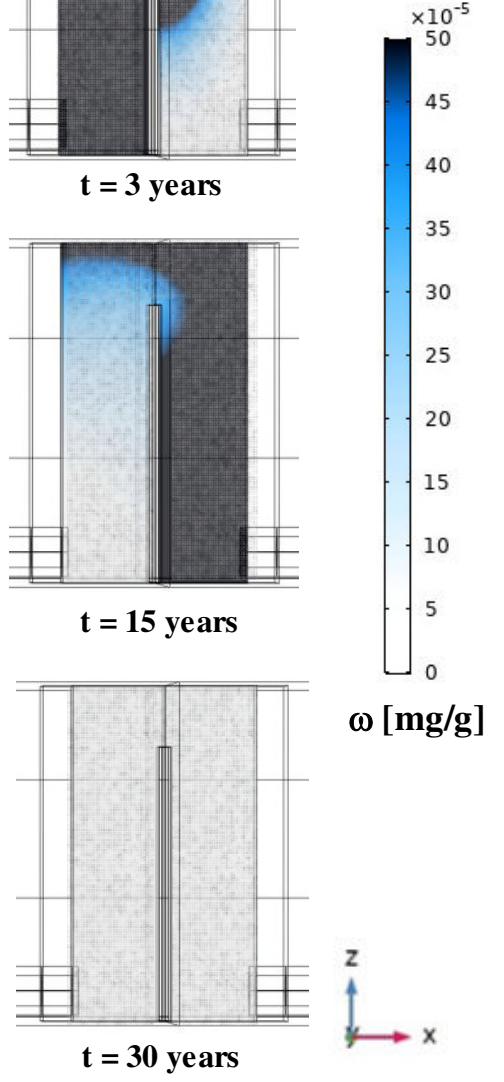

Figure 6. Chromium adsorbed concentration, $\omega$, in In-DRAIN-TREAT reactive cell over time.

Figures 8 and 9 show the $\mathrm{Cr}^{\mathrm{VI}}$ breakthrough curves for In-DRAIN-TREAT and the PAB, respectively, over a period of 30 years. These curves illustrate the pollutant concentration variation over the simulation time at both inlet (in red) and outlet (in blue) of each configuration, and compared with the Italian regulatory limit $\left(C_{l i m}\right)$ of $5 \mu \mathrm{g} / \mathrm{L}(\mathrm{LD}, 2006)$. While, for In-DREAT-TREAT, the red and blue lines correspond to the concentration trends at the treatment cell inlet and outlet, for the PAB, they correspond to the trends revealed at the points $\mathrm{A}$ and $\mathrm{B}$, located respectively at the barrier inlet and outlet, with coordinates $(\mathrm{x} ; \mathrm{y} ; \mathrm{z})$ 
equal to $(40 ; 15 ; 2.7)$ and $(41 ; 15 ; 2.7)$.

As shown, the $\mathrm{Cr}^{\mathrm{VI}}$ inlet concentration peak in the case of In-DRAIN-TREAT corresponds to $45 \mu \mathrm{g} / \mathrm{L}$ while it is approximately $52 \mu \mathrm{g} / \mathrm{L}$ in case of the PAB, despite the two technologies were located at the same distance from the plume (equal to the length of the inlet drain, $L_{i n}$ ). This highlights the dilution action of In-DRAIN-TREAT by the hydrodynamic effect of the drains in the aquifer. Furthermore, in case of the barrier, the $\mathrm{Cr}^{\mathrm{VI}}$ peak values required one additional year to reach the treatment area (Figures 7 and 9). Finally, for both the configurations, the outlet $\mathrm{Cr}^{\mathrm{VI}}$ concentrations resulted lower than the threshold considered, during both adsorption and desorption phenomena. Although In-DRAIN-TREAT outlet concentrations are lower and desorbed in a shorter time period.
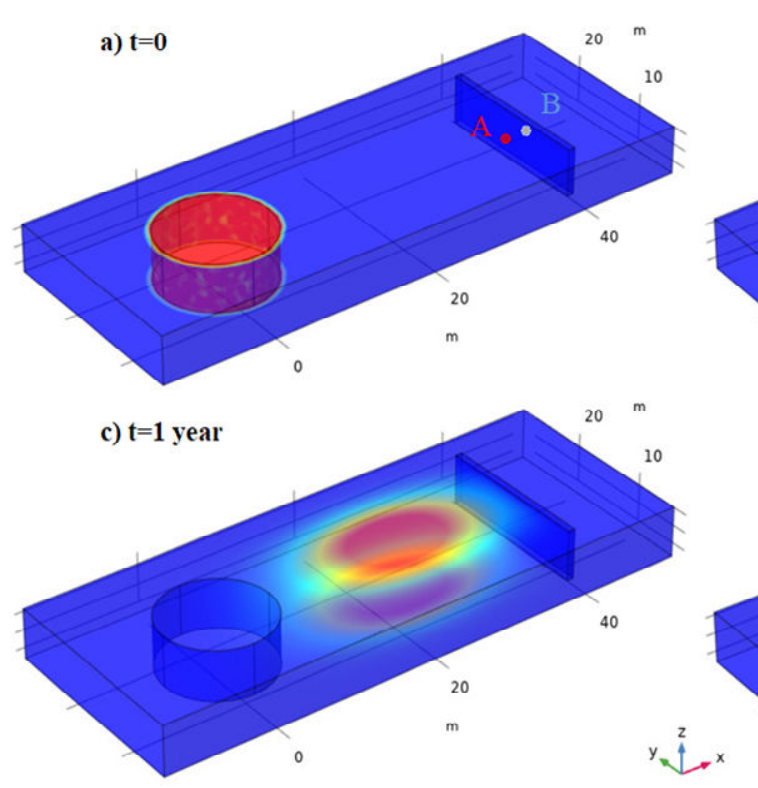

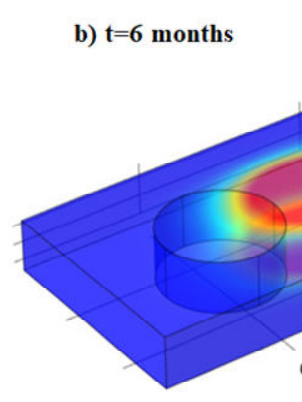

Figure 7. Chromium concentration plume at (a) $t=0$ and after respectively (b) 6 months, (c) 1 year and (d) 2 years of PAB, with indicative representation of points A and B. 


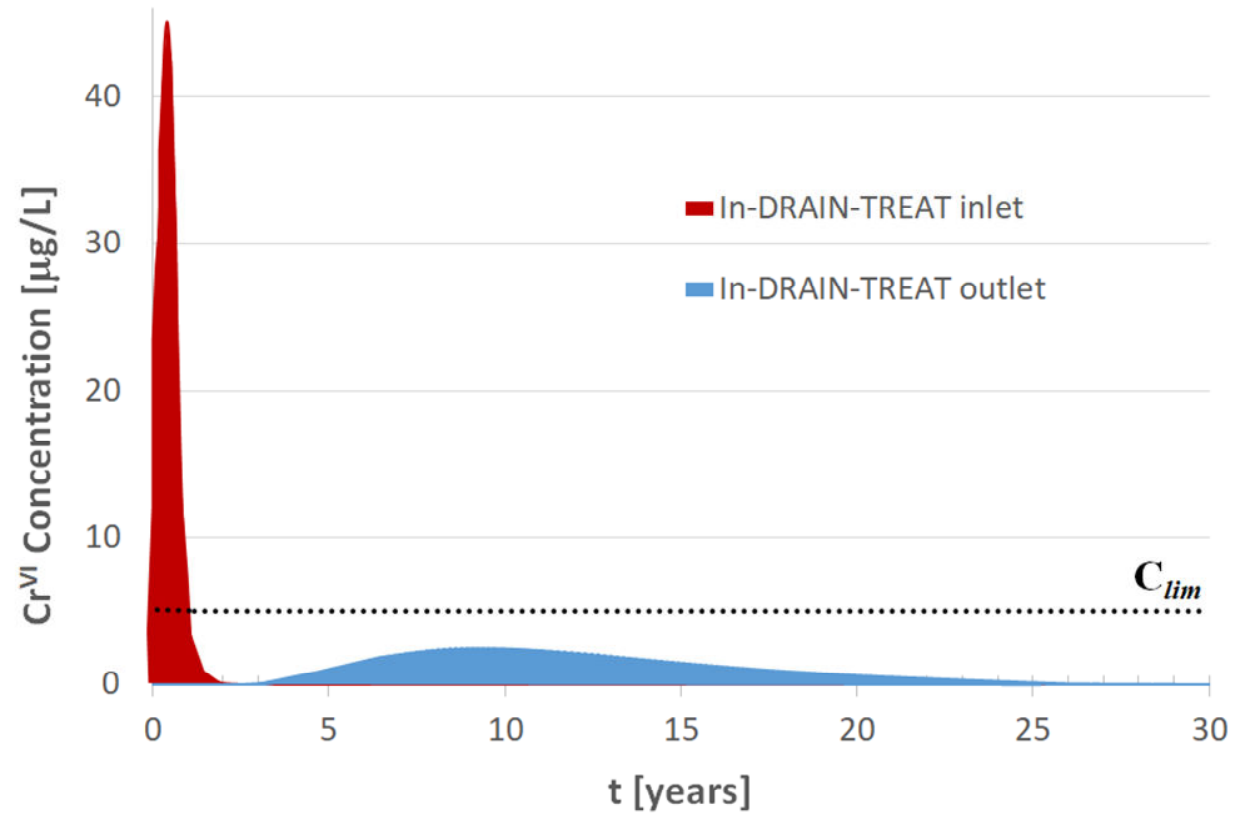

Figure 8. In-DRAIN-TREAT maximum inlet and outlet $\mathrm{Cr}^{\mathrm{VI}}$ concentrations over the time.

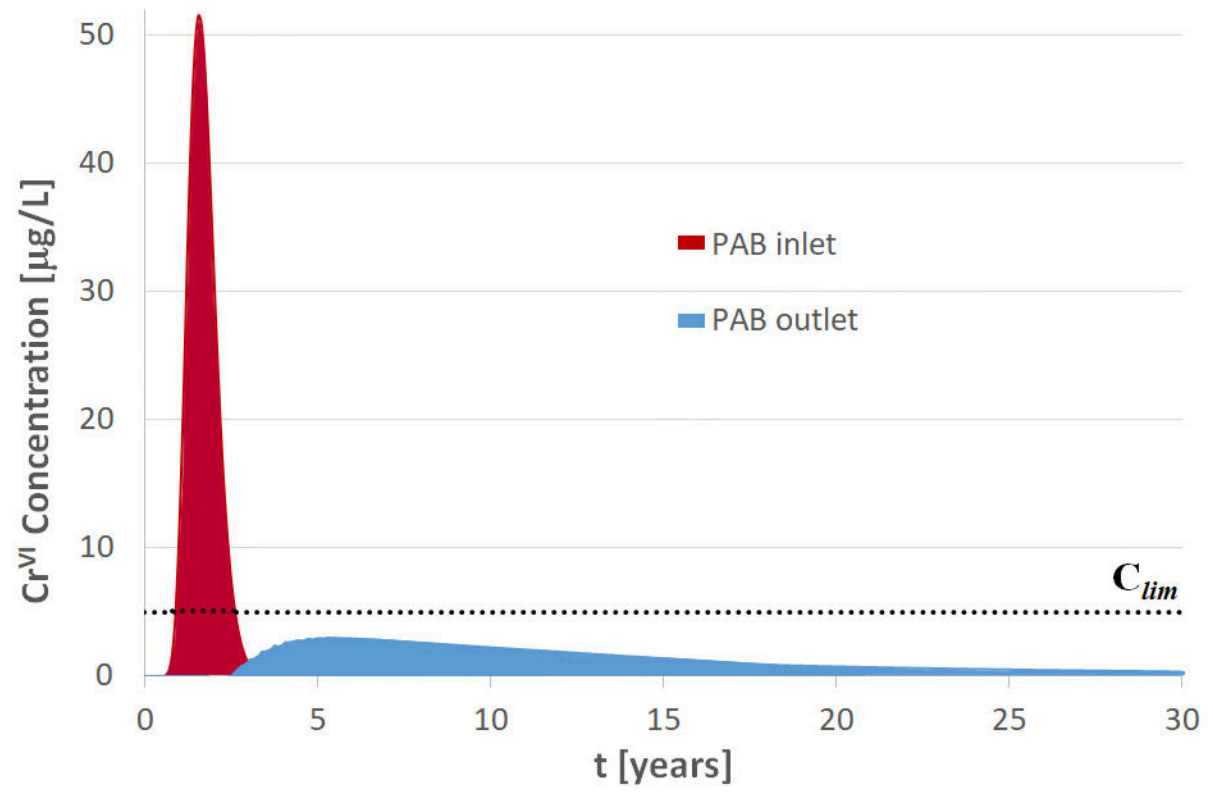

Figure 9. $\mathrm{PAB}$ maximum inlet and outlet $\mathrm{Cr}^{\mathrm{VI}}$ concentrations over the time, respectively at points A and B.

In Table 3 a comparison between the required adsorbing material for In-DRAIN-TREAT and PAB is also reported. 
Table 3. Comparison of In-DRAIN-TREAT and PAB volume.

\begin{tabular}{cccccc}
\hline & $\begin{array}{c}\text { Height, } \boldsymbol{H} \\
{[\mathrm{m}]}\end{array}$ & $\begin{array}{c}\text { Width, } \boldsymbol{W} \\
{[\mathbf{m}]}\end{array}$ & $\begin{array}{c}\text { Length, } \boldsymbol{L} \\
{[\mathbf{m}]}\end{array}$ & $\begin{array}{c}\text { Volume, } \boldsymbol{V}_{\boldsymbol{a d}} \\
{\left[\mathbf{m}^{3}\right]}\end{array}$ & $\begin{array}{c}\Delta \boldsymbol{V}_{\boldsymbol{a d}} \\
{[\%]}\end{array}$ \\
\hline In-DRAIN-TREAT cell & 5.5 & 3 & 2 & 30.8 & \\
PAB & 5.5 & 0.8 & 19 & 84 & $63 \%$ \\
\hline
\end{tabular}

The volume of the In-DRAIN-TREAT cell was calculated by considering the space occupied by the adsorbing material, i.e. subtracting the baffle volume, corresponding to $2.2 \mathrm{~m}^{3}$, from the volume cell. As shown, the In-DRAIN-TREAT allows for a $63 \%$ volume reduction of adsorbing material with respect to PAB.

In addition, a preliminary cost analysis was carried out to assess the remediation $\operatorname{cost}\left(C_{R}\right)$ of each configuration (Eq. (5)), as reported in Table 4 . To this aim, drilling costs $\left(C_{\text {Drill }}\right)$, adsorbing material costs $\left(C_{A d}\right)$ and monitoring costs $\left(C_{M}\right)$ were considered, for which the corresponding unit values are reported in Table 4.

$C_{R}=C_{\text {Drill }}+C_{A d}+C_{M}$

Table 4. In-DRAIN-TREAT and PAB unit costs.

\begin{tabular}{|c|c|c|c|c|}
\hline \multirow{3}{*}{ In DRAIN-TREAT } & & $C_{\text {Drill }}$ & $C_{A d}$ & $C_{M}$ \\
\hline & $D[\mathrm{~m}]$ & $\begin{array}{c}\text { Unit cost } \\
{[€ / \mathrm{m}]}\end{array}$ & $\begin{array}{l}\text { Unit cost } \\
{\left[€ / \mathbf{m}^{3}{ }_{A d}\right]}\end{array}$ & {$[\mathbf{k} €]$} \\
\hline & 0.5 & $150-300$ & $700-900$ & 250 \\
\hline \multirow{3}{*}{ PAB } & & $C_{\text {Drill }}$ & $C_{A d}$ & $C_{M}$ \\
\hline & $W[\mathbf{m}]$ & $\begin{array}{c}\text { Unit cost } \\
{[€ / \mathbf{m}]}\end{array}$ & $\begin{array}{l}\text { Unit cost } \\
{\left[€ / \mathbf{m}^{3} \text { Ad }\right]}\end{array}$ & {$[\mathbf{k} €]$} \\
\hline & 0.8 & $70-90$ & $700-900$ & 250 \\
\hline
\end{tabular}

Being both the technologies classified as passive remediation techniques, the operation and maintenance costs were neglected at this stage, for the minimal energy costs required (Santonastaso et al., 2017). For both $C_{D r i l l}$ and $C_{A d}$, a low and high estimate were applied to 
account for possible contingencies associated to the two technologies, being them highly dependent on the site conditions and specific well design requirements.

In Table 5 the total remediation costs obtained are listed for both the cases. The drilling costs of In-DRAIN-TREAT were calculated by considering the drilling costs for the horizontal wells, ranging from 150 to $300 € / \mathrm{m}$ (Divine et al., 2018) and the excavation cost to create the cell, which were considered corresponding to the drilling costs of a PAB ranging from 70 to $90 € / \mathrm{m}$ (Santonastaso et al., 2017) (Table 4).

Table 5. Comparison of In-DRAIN-TREAT and PAB costs.

\begin{tabular}{cccccc}
\hline & $\boldsymbol{C}_{\text {Drill }}[\mathrm{k} €]$ & $\boldsymbol{C}_{\boldsymbol{A d d}}[\mathrm{k} €]$ & $\boldsymbol{C}_{\boldsymbol{M}}[\mathrm{k} €]$ & $\boldsymbol{C}_{\boldsymbol{R}}[\mathrm{k} €]$ & $\Delta \boldsymbol{C}_{\boldsymbol{R}}[\%]$ \\
\hline In-DRAIN-TREAT & $11.5-21.4$ & $21.6-27.7$ & 250 & $283.0-299.1$ & \multirow{2}{*}{$\mathbf{1 1}$} \\
PAB & $7.3-9.4$ & $58.5-75.2$ & 250 & $315.8-334.6$ & \\
\hline
\end{tabular}

In Table 5 it is evident that In-DRAIN-TREAT also allows a reduction of remediation costs of $10-11 \%$.

\section{Discussion}

In-DRAIN TREAT works as a directional submerged drainage system, which effectively collects the contaminated water. The hydraulic performance and capture zone of this technology has shown to be easily predictable and can be optimised with identified design parameters. Given that the contaminated water, directed to the cell, is diluted under the draining effect, the overall volume of adsorbing material needed for the treatment is optimised, thus further minimising the remediation costs. Additionally, for smaller contamination plumes, it is possible to use only part of the treatment cell, which would in turn further reduce the treatment volume and costs.

In-DRAIN-TREAT is part of a new generation of integrated environmental restoration solutions that provides profitable and sustainable results to some of the most challenging 
environmental clean-up problems. The approach requires no above-ground treatment, minimal footprint and limited ongoing maintenance, which reduces deployment risks, with the possibility of combining multiple drains or pumping.

When the drainage system is positioned as closely as possible to the contaminated plume, this maximises the screen contact with the polluted water. Different drain diameters and inclinations can be combined to improve the effectiveness and treatment time. In-DRAINTREAT is particularly suitable for sites where long-term mass discharge control is a primary performance objective. Field monitoring and laboratory analyses should verify the performance of operating In-DRAIN-TREAT configurations, with provisions for evaluating plume containment, residual contaminant levels, and the condition of reactive media. InDRAIN-TREAT may not be suited to all situations, including aquifers with low solubility contaminants or high groundwater velocity.

The results presented in this paper validate the concept related to In-DRAIN-TREAT, by providing a basis for more detailed future modelling evaluations. Additional aspects that should be considered in future research include:

- Complex aquifer geometries and multi component contamination;

- Accurate sensitivity analysis on the variation of multiple drain length, orientation, screen and treatment.

- Performance implications in case of clogging phenomena or variation of hydraulic conductivities over time.

\section{Conclusions}

This paper presents the numerical proof of concept and the design of a new technology for the remediation of a contaminated aquifer, named In-DRAIN-TREAT. In-DRAIN-TREAT is an innovative passive treatment technique, which combines drainage systems for a "directional" 
polluted water collection and in-situ passive treatment. The contaminated groundwater is collected by means of horizontal drains, located longitudinally to the flow direction, which direct it to a waterproofed cell. Here, the water flows through a reactive media, via the groundwater natural gradient, and is passively treated.

A 3D numerical model was developed to describe pollutant transport within groundwater and pollutant adsorption in the treatment cell. The numerical model was applied to a theoretical case study represented by a hexavalent chromium contaminated aquifer. The optimal technology properties (location, orientation and dimensions) were defined via a "trial and error" procedure, for which a range of values were assumed. The results, obtained for a case study, show that $\mathrm{Cr}^{\mathrm{VI}}$ concentration outflowing is lower than the stated regulatory limit throughout the whole computational domain and over the simulation time. Consequently, the overall volume needed for the treatment is optimised, thus reducing the remediation costs. A comparison with an alternative technology for groundwater remediation (i.e. a Permeable Adsorbing Barrier) showed that a $10-11 \%$ cost saving can be assured by adopting the In-

\section{DRAIN-TREAT.}

This technology has the ability to significantly improve the management of groundwater pollution source zones, and can provide a reliable method for controlling contaminant migration and mass discharge that: (1) requires little long-term maintenance, (2) can be applied in complex geological settings and multiple contamination, (3) reduces impact on surface operations, (4) has accessible treatment and/or (5) translates to significantly reduced lifecycle costs over currently available alternatives. Furthermore, the reactive material once saturated can be totally removed from the environment, favoring the groundwater protection.

\section{References}


Bortone I., Chianese S., Erto A., Di Nardo A., De Crescenzo C., Karatza D., Santonastaso G.F. Musmarra D. (2019) An optimised configuration of adsorptive wells for the remediation of an aquifer contaminated by multiple aromatic hydrocarbon pollutants. Science of the Total Environment, 696 (133731).

Bortone I., Chianese S., Di Nardo A., Santonastaso G., Erto A., Musmarra D. (2013a) A comparison between Pump \& Treat technique and permeable reactive barriers for the remediation of groundwater contaminated by chlorinated organic compounds. Chemical Engineering Transaction, 32, 31-36

Bortone I., Di Nardo A., Di Natale M., Erto A., Musmarra D. (2013b) Remediation of an aquifer polluted with dissolved tetrachloroethylene by an array of wells filled with activated carbon. Journal of Hazardous Material, 260, 914-920.

Carey M. A., Finnamore J. R., Morrey M. J. Marsland P.A. (2000) Guidance on the Assessment and Monitoring of Natural Attentuation of Contaminants in Groundwater. Environment Agency, UK.

Ceulemans, P., Labeeuw V. (2013) Code of Good Practice: In-situ Chemical Oxidation. CityChlor, $112 \mathrm{pp}$.

Chen J., Xiu Z., Lowry G.V., Alvarez P.J.J. (2011) Effect of natural organic matter on toxicity and reactivity of nano-scale zero-valent iron. Water Resources, 45, 1995-2001. 
Di Natale F., Erto A., Lancia A., Musmarra D. (2015). Equilibrium and dynamic study on hexavalent chromium adsorption onto activated carbon. Journal of Hazardous Materials, 281, 47-55.

Divine C.E., Wright J., Wang J., McDonough J., Kladias M., Crimi M., Nzeribe B.N., Devlin J.F., Lubrecht M., Ombalski D., Hodge B., Voscott H., Gerber K. (2018) The horizontal reactive media treatment well (HRX Well) for passive in-situ remediation: Design, implementation and sustainability considerations. Remediation, 28, 5-16.

EPA, U.S. Enviornmental Protection Agency (2008) Green Remediation: Incorporating sustainable environmental practices into remediation of contaminated sites. EPA 542-R-08002, Washington, D.C.

EPA, U.S. Enviornmental Protection Agency (2005) Cost-Effective Design of Pump and Treat Systems. EPA 542-R-05-008, Washington, D.C.

EPA, U.S. Enviornmental Protection Agency (2004) Cleaning up the Nation's Waste Sites. EPA 542-R-04-015, Washington, D.C.

EPA, U.S. Enviornmental Protection Agency (1999) Groundwater Cleanup: Overview of Operating Experience at 28 Sites. EPA 542-R-99-006, Washington, D.C.

Erto, A., Bortone, I., Di Nardo, A., Di Natale, M., Musmarra, D. (2014). Permeable Adsorptive Barrier $(\mathrm{PAB})$ for the remediation of groundwater simultaneously contaminated by some chlorinated organic compounds. Journal of Environmental Management, 140, 111-119. 
Erto A., Lancia A., Bortone I., Di Nardo A., Di Natale M., Musmarra D. (2011) A procedure to design a Permeable Adsorptive Barrier (PAB) for contaminated groundwater remediation. Journal of Environmental Management, 92(1), 23-32.

Fetter C. W. (1993) Contaminant Hydrogeology. 2nd Ed. Ch. 2.6: Derivation of the Advection Dispersion Equation for Solute Transport. New Jersey: Prentice-Hall.

Gavaskar A., Gupta N., Sass B., Janosy R., Hicks J. (2000) Design Guidance for Application of Permeable Reactive Barriers for Groundwater Remediation. NSN 7540-01-280-5500, Columbus, O.H.

Gelhar L.W., Welty C., Rehfeldt K. R. (1992) A critical review of data on field-scale dispersion in aquifers. Water Resource Research, 28, 1955-1974.

Hudak P.F. (2017) Large-diameter, non pumped wells filled with reactive media for groundwater remediation. Environment and Earth Science, 76, 667.

Khalid S., Shahid M., Niazi N. K., Murtaza B., Bibi I., Dumat C. (2016) A comparison of technologies for remediation of heavy metal contaminated soils. Journal of Geochemical Exploration, 182, 247-268.

Key K. C., Sublette K. L., Johannes T.W., Raes E., Sullivan E., Duba J., Ogles D., Baldwin B. R., Biernacki A. (2013) An In Situ Bioreactor for the Treatment of Petroleum Hydrocarbons in Groundwater. Remediation, 23(3), 55-84. 
Kompani-Zare M., Zhan H. (2006) Steady flow to horizontal drain in an unconfined aquifer with variable thickness. Journal of hydrology, 327, 174-185.

LD, Legislative Decree 152/2006 (2006) Environmental Protection Code, Testo Unico Ambientale 152/2006. Available online at:

https://www.camera.it/parlam/leggi/deleghe/06152dl2.htm [accessed on 29/03/20] (in italian).

Musmarra D., Di Natale M., Bortone I., Erto A. Ciarmiello M. (2015) Remediation of thalliumcontaminated groundwater by permeable adsorptive barrier. Procedia Environmental Sciences $25,175-182$.

NRC, National Research Council. (1997) Innovations in Ground Water and Soil Cleanup: From Concept to Commercialization. Washington, DC: The National Academies Press.

Perry R.H., Green D.W. (2007) Perry's Chemical Engineers' Handbook. McGraw-Hill.

Phifer M.A., Sappington F.C., Nichols R.L., Dixon K.L. (1999) TNX GeoSiphon Cell (TGSC1) Phase II Deployment/Demonstration Final Report (U), WSRC-TR-99-00432, Aiken, SC.

Santonastaso G.F., Erto A., Bortone I., Chianese S., Di Nardo A., Musmarra D. (2018) Experimental and simulation study of the restoration of a thallium (I)-contaminated aquifer by Permeable Adsorptive Barriers (PABs). Science of the Total Environment, 630, 62-71.

Santonastaso G.F., Bortone I., Chianese S., Di Nardo A., Di Natale M., Erto A., Karatza D., Musmarra M. (2017) Discontinuous permeable adsorptive barrier design and cost analysis: a 
methodological approach to optimisation. Environmental Science Pollution Research, 25, 26793-26800.

Söderlind G., Wang L. (2006) Adaptive time-stepping and computational stability. Journal of Computational and Applied Mathematics, 185, 225-243.

Swartjes F.A. (2011) Book on Contaminated Sites. Springer, ISBN: 9789048197.

Tabatabaian M. (2014) COMSOL® for Engineers. British Columbia Institute of Technology, pp. 254. ISBN: 978-1-938549-53-3

Van Heest G. (2013) Horizontal Wells for groundwater remediation: How a technology that revolutionised the oil industry is used to remediate groundwater. Air \& Waste Management Association. 


\section{An innovative In-situ DRAINage system for advanced groundwater reactive TREATment (In-DRAIN-TREAT)}

Bortone I., Santonastaso G., Erto A., Chianese S. ${ }^{2}$, Di Nardo A. ${ }^{2}$, Musmarra D. ${ }^{2}$

\section{SM- Supplementary Material}

The governing equation describing the $3 \mathrm{D}$ transport of contaminant with concentration, $C$, over time, $t$, through an aquifer is described as follows (Fetter, 1993):

$\theta \frac{\partial C}{\partial t}=\theta \nabla \cdot\left(D_{h} \nabla C\right)-\theta \bar{u} \nabla C$

Which combines the effect of advection and dispersion mechanisms in soil with porosity $\theta$.

The hydrodynamic dispersion coefficient, denoted with $D_{h}$, is defined as the sum of the tensor of mechanical dispersion, $D$, and the molecular diffusion coefficient, $D^{*}$ (Gelhar et al., 1992). The components of the mechanical dispersion tensor are:

$\left[\begin{array}{l}D_{x x}=\alpha_{L} u_{x}^{2} /|\boldsymbol{u}|+\alpha_{T}\left(\left(u_{y}^{2}+u_{z}^{2}\right) /|\boldsymbol{u}|\right) \\ D_{y y}=\alpha_{L} u_{y}^{2} /|\boldsymbol{u}|+\alpha_{T}\left(\left(u_{x}^{2}+u_{z}^{2}\right) /|\boldsymbol{u}|\right) \\ D_{z z}=\alpha_{L} u_{z}^{2} /|\boldsymbol{u}|+\alpha_{T}\left(\left(u_{x}^{2}+u_{y}^{2}\right) /|\boldsymbol{u}|\right) \\ D_{x y}=D_{y x}=\left(\alpha_{L}-\alpha_{T}\right) u_{x} u_{y} /|\boldsymbol{u}| \\ D_{y z}=D_{z y}=\left(\alpha_{L}-\alpha_{T}\right) u_{y} u_{z} /|\boldsymbol{u}| \\ D_{x z}=D_{z x}=\left(\alpha_{L}-\alpha_{T}\right) u_{x} u_{z} /|\boldsymbol{u}|\end{array}\right.$

where $\alpha_{L}$ and $\alpha_{T}$ are the longitudinal and transverse dispersivities, respectively, and depend on the porosity and tortuosity of a particular soil. Longitudinal dispersivity can be experimentally obtained and varies with the fluid, media and contaminant characteristics (Gelhar et al., 1992), while transverse dispersivity typically follow the relationship given by Eq. SM(3). ${ }^{i}$ 
$\alpha_{L}=10 \alpha_{T}$

$\operatorname{SM}(3)$

The advective flux through a porous medium, second term on the right hand side of Eq. SM(1) is dependent on the velocity vector, $\bar{u}$ described by the Darcy's law,

$\bar{u}=-K_{s} \cdot \bar{\nabla} h$

where $K_{S}$ is the hydraulic conductivity of the soil and $\bar{\nabla} h$ is the hydraulic head gradient vector. By coupling Eqs. SM(1) and SM(2), the model can predict the profile of hydraulic head and contaminant distribution over time, enabling also to find the best well configuration and placement.

In Eq. SM(1), it is assumed that no natural attenuation takes place, hence there is no adsorption term in the aquifer. Although adsorption occurs in the treatment cell, in which Eq. SM(1) modifies as:

$\theta_{c} \frac{\partial C}{\partial t}=\theta_{c} \nabla \cdot\left(D_{h} \nabla C\right)-\theta_{c} \bar{u} \nabla C-\rho_{c} \frac{\partial \omega}{\partial t}$

In Eq. $\operatorname{SM}(5)$ the parameters of the cell have been indicated with the subscript " $c$ ". The last term on the right-hand side of Eq. SM(5) describes the capture of the pollutant dissolved in water by the adsorbing media, i.e. the variation of the adsorption capacity, $\omega$, over time, $t$, corresponding to

$\rho_{c} \frac{\partial \omega}{\partial t}=k_{t} a\left[C-C^{*}(\omega)\right]$ 
where $\rho_{c}$ is the bulk density of the media, $k_{t}$ is the mass transfer coefficient for adsorption reaction, $a$ is the external specific surface area of adsorbent particles and $C^{*}(\omega)$ is the term deriving from the adsorption isotherm of the contaminant on the adsorbent material (i.e. the equilibrium concentration between pollutant concentration in the liquid phase and the amount adsorbed over the solid surface).

The initial and boundary conditions used for both Darcy equation (Eq. SM(4)) and concentration fields (Eq. SM(1)), are given below.

$$
\left[\begin{array}{cc}
h(x, y, z, t)=h_{1} & x=0 ; \forall t \\
h(x, y, z, t)=h_{2} & x=X ; \forall t \\
-n \bar{u}=0 & x=0, x=X ; \quad \forall y \forall z \forall t \\
& y=0, y=Y ; \quad \forall x \forall z \forall t
\end{array}\right.
$$

$\left[\begin{array}{ll}C(x, y, z)=C_{0} & t=0 \\ C(x, y, z, t)=0 & x=0 ; \forall y \forall z \forall t \\ -\nabla\left(D_{h} \nabla C\right)+\bar{u} \nabla C=0 & x=X ; \forall x \forall y \forall t\end{array}\right.$

In Eqs. $\mathrm{SM}(7)$ and $\mathrm{SM}(8), n$ is the unit vector normal to the boundary, while $\mathrm{X}, \mathrm{Y}$ and $\mathrm{Z}$ represent the size of the computational domain along the $x, y$ and $z$ directions; $h_{1}$ and $h_{2}$ are the hydraulic head values at the inlet and at the outlet of the model respectively.

The equation system $\operatorname{SM}(1)$ - SM(6), with the related initial and boundary conditions $\operatorname{SM}(7)$ and $\operatorname{SM}(8)$ were solved numerically via the finite element method implemented in COMSOL Multi-physics ${ }^{\circledR}$ software (Bortone et al., 2019), which allowed to predict the contaminant transport in the aquifer, its capture in the treatment cell and the groundwater flux over time (Tabatabaian, 2014). Specifically, COMSOL pre-defined modules "Darcy's Law" and "Solute Transport" were used to describe the subsurface flow and solute transport and to solve Eqs. $\operatorname{SM}(1)-\operatorname{SM}(4)$, whilst Eqs. SM(5) and SM(6) were implemented via an ad-hoc "user-defined 
physic", to describe the adsorption and desorption phenomena both in the reactive cell and barrier. 